\title{
Aktivitas Antibakteri Ekstrak Metanol Buah Mbosi (Dysoxylum gaudichandianum (A.Juss) Miq.) dan Penapisan Senyawa Kimianya
}

\author{
Antibacterial Activity of Mbosi (Dysoxylum gaudichandianum (A.Juss) Miq.) Fruit \\ Methanol Extract and Its Phytochemical Screening
}

\author{
Praptiwi $^{1^{*}}$ dan Mindarti Harapini ${ }^{1}$
}

Lab. Treub, Bidang Botani-Puslit Biologi, Jl. Ir. H. Juanda 22-24, Bogor, 16122

Telp. : (0251)-324616 E-mail:herbogor@indo.net.id *Penulis untuk korespondensi

\begin{abstract}
Mbosi (Dysoxylum gaudichandianum (A.Juss) Miq.) belongs to Meliaceae family, Its potential bioactivity had not been known although the other plants from the same family had been known as natural insectiside or medicinal plants. Phytochemical screening showed that mbosi fruit contained fat, fatty acid, sterol, triterpenoide, tannin, peroxide sugar, alkaloid, steroid glycoside and flavonoid. Identification of mbosi fruit chemical compounds by GC-MS showed that it contained 16 compounds. Compounds with the concentration more than $5 \%$ were butyl cellosolve $(11.1 \%)$, erythritol $(8.48 \%)$, glycerol $(10.32 \%)$, hexadecanioc acid palmitinic ester (16.2\%), oleic acid $(65.3 \%)$ and ethyl oleat (6.2\%). In-vitro antibacterial test on innoculated Mueller Hinton Agar to seven bacteria isolates (Salmonella typhimurium, S. typhii, Eschechiria coli ATCC 25923, Pseudomonas sp., Staphylococcus aureus ATCC 25922, S. epidermidis, and Bacilus subtilis) showed that $20 \%$ methanol extract inhibit only the growth of Staphylococcus aureus.
\end{abstract}

Key words: Dysoxylum gaudichandianum, phytochemical screening, antibacterial

Diterima: 04 Maret 2004, disetujui: 31 Maret 2004

\section{Pendahuluan}

Indonesia mempunyai lebih kurang 30.000 spesies tumbuhan, dan 7500 spesies diantaranya dikenal sebagi tumbuhan obat. Pemanfaatan tumbuhan sebagai bahan obat di Indonesia pada umumnya berdasarkan pada pengetahuan empiris. Menurut Cholid (2003) penggunaan 'herbal medicines' dibagi menjadi tiga kategori yaitu untuk pencegahan penyakit (48.9\%), menjaga kesehatan $(22.47 \%)$ dan pengobatan $(21.78 \%)$.

Keanekaragaman tumbuhan menimbulkan keanekaragaman kandungan kimia, dimana kandungan kimia tersebut kemungkinan dapat dijadikan sebagai sumber senyawa yang bersifat bioaktif antara lain sebagai bahan obat.

Beberapa jenis tumbuhan dari famili Meliaceae telah diketahui pemanfaatannya sebagai bahan obat maupun insektisida. Menurut Nugroho (1996) Aglaia duppereana dapat dimanfaatkan sebagai insektisida alami karena mengandung alkaloida rocaglamide dengan nilai $\mathrm{LC}_{50} 0.9$ ppm. Beberapa tumbuhan dari suku Meliaceae yang telah dimanfaatkan sebagai bahan obat antara lain kulit batang Toona sureni yang digerus dengan Acorus calamus dapat digunakan sebagai obat demam, sedangkan Azadirachta indica dimanfaatkan sebagai obat malaria karena mempunyai rasa pahit dan mengandung azadirachtin.

Mbosi (Dysoxylum gaudichandianum) merupakan salah satu jenis tumbuhan anggota Meliaceae berbentuk pohon dengan tinggi dapat mencapai $50 \mathrm{~m}$, biasanya tumbuh pada ketinggian 50-500 m dpl (Heyne, 1987). Pengungkapan potensi buah mbosi belum 
banyak dilakukan. Berdasarkan nilai peroksidanya diketahui bahwa ekstrak etanol buah mbosi mempunyai nilai peroksida (68.90) lebih kecil dari $\alpha$-tokoferol (212.52) (Chairul, 2002). Hal ini merupakan petunjuk awal bahwa ekstrak tersebut mempunyai sifat antioksidan yang cukup baik.

Pemanfaatan tumbuhan sebagai bahan obat berkaitan dengan adanya senyawa yang bersifat bioaktif pada tumbuhan tersebut. Salah satu sifat bioaktif dari senyawa pada tumbuhan adalah sebagai antibakteri. Seperti diketahui bakteri patogen dapat menimbulkan masalah yang serius pada manusia, sedang disisi lain banyak isolat bakteri yang resisten terhadap antibiotik. Oleh sebab itu perlu dicari sumber bahan antibakteri yang baru. Penelitian ini bertujuan untuk mengungkapkan poteni buah mbosi terutama sebagai bahan antibakteri.

\section{Bahan dan Metode}

\section{Bahan Penelitian}

Bahan penelitian berupa buah mbosi ( $D$. gaudichandianum) yang diperoleh dari desa Pakuli di sekitar Taman Nasional Lore Lindu (Sulteng). Determinasi tumbuhan dilakukan di Herbarium Bogoriense. Buah mbosi yang diperoleh dipotong-potong dan dikeringkan di bawah sinar matahari. Setelah kering, buah mbosi digiling menjadi serbuk.

\section{Ekstraksi}

Ekstraksi untuk uji antibakteri dilakukan dengan menggunakan pelarut methanol $80 \%$. 100 gram serbuk buah mbosi dimaserasi dengan methanol $80 \%$. Filtrat yang ada ditampung dan dikumpulkan. Selanjutnya filtrat tersebut diuapkan dengan rotary evaporator untuk mendapatkan ekstrak pekat (Harborne, 1984).

\section{Penapisan Fitokimia}

Penapisan fitokimia dilakukan untuk mengetahui senyawa yang terdapat buah mbosi. Penapisan fitokimia dilakukan pada sari eter, alkohol, alkohol terhidrolisis dan sari air dengan metoda Cuiley (1984).

\section{Analisis Khromatografi Gas- Spektrometri Massa (GC-MS)}

Analisis dengan menggunakan GC-MS dilakukan untuk identifikasi komponen kimia berdasarkan spektrum massa dari komponen yang bersangkutan, lalu dibandingkan dengan spektrum baku yang terdapat pada sistim data (Munson, 1991). Analisis GC-MS terhadap ekstrak metanol buah mbosi dilakukan di laboratorium Doping - Departemen Kesehatan, Jakarta (Agilent Technologies 6890 Gas Chromatograph with auto sampler and 5973 Mass Selective Detector and Chemstation Data System). Kolom yang digunakan adalah $\mathrm{Hp}$ ultra 2 capillary column. Suhu awal oven $70 \mathrm{oC}$ selama 1 menit, dinaikkan 3oC/menit sampai mencapai suhu 1500 C. Suhu dipertahankan selama 1 menit selanjutnya dinaikkan hingga mencapai 230 oC dan dipertahankan pada suhu tersebut selama 3 menit. Total waktu running adalah 45 menit. Suhu injeksi $250 \mathrm{oC}$ sedang suhu interface $280 \mathrm{oC}$. Gas pembawa yang dugunakan adalah helium (He), dengan volume injeksi $2 \mu 1$.

\section{Uji Antibakteri}

Ekstrak metanol buah mbosi diuji daya antibakterinya terhadap beberapa bakteri patogen yaitu bakteri Gram Negatif (Salmonella typhymurium ATCC 25920, Salmonella typhii ATCC 25921, Escherichia coli ATCC 25923, Pseudomonas sp.) dan bakteri Gram Positif (Staphylococcus aureus ATCC 25922, Bacilus subtilis ATCC 25924 , Staphylococcus epidermidis ATCC 25926 strain cowan). Isolat bakteri diperoleh dari koleksi biakan Balai Penelitian Veteriner, Bogor. Masing-masing ekstrak dilarutkan dalam DMSO dengan konsentrasi $20 \%$ dan $10 \%$. Masing-masing perlakuan mempunyai tiga ulangan. Lima belas mikroliter ekstrak diteteskan pada kertas cakram steril, selanjutnya diletakkan pada media Mueller Hinton Agar (MHA) yang telah diinokulasi dengan isolat bakteri uji. Media tersebut selanjutnya diinkubasi pada suhu $37^{\circ} \mathrm{C}$ selama 24 jam (Simmons dan Craver, 1980). Pengamatan terhadap adanya sifat antibakteri ditandai dengan adanya penghambatan pertumbuhan bakteri disekitar kertas cakram. 
Diameter penghambatan pertumbuhan bakteri yang terbentuk disekitar kertas cakram diukur.

\section{Hasil dan Pembahasan}

Penapisan fitokimia dilakukan sebagai analisis awal untuk mengetahui senyawasenyawa yang terdapat pada buah mbosi (Tabel 1). Berdasarkan hasil pada Tabel 1. ternyata buah mbosi mengandung lemak dan asam lemak, sterol dan triterpenoida, tannin, gula pereduksi, garam alkaloida, glikosida steroid dan flavonoid. Beberapa senyawa yang terdapat pada buah mbosi tersebut kemungkinan dapat bersifat bioaktif. Misal: flavonoida merupakan kelompok senyawa fenolik yang disintesis oleh tumbuhan (Robinson, 1991). Selanjutnya Robinson (1991) menyatakan bahwa flavonoid pada tumbuhan dapat berperan untuk pengaturan fotosintesis, antimikroba dan antivirus. Analisis lebih lanjut menggunakan Gas Chromatography-Mass Spectrometry (GC-MS) pada ekstrak metanol buah mbosi menunjukkan adanya beberapa asam lemak yaitu asam linoleat, asam linolenat, asam oleat sebagai komponen utama $(65.3 \%)$, ethyl oleat dan methyl oleat (Tabel 2). Tyler et al. (1988) menyatakan bahwa asam oleat dimanfaatkan sebagai emulsi, sedangkan ethyl oleat biasanya dimanfaatkan sebagai 'pharmaceutic vehicle'.

Tabel 1. Kandungan senyawa kimia pada buah mbosi

\begin{tabular}{|c|c|c|}
\hline No & Senyawa & Hasil uji \\
\hline 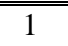 & Minyak atsiri & - \\
\hline 2 & Lemak dan asam lemak & + \\
\hline 3 & Sterol dan triterpenioda & + \\
\hline 4 & Alkaloida basa & - \\
\hline 5 & Aglikon flavonoid & - \\
\hline 6 & Tannin & + \\
\hline 7 & Gula pereduksi & + \\
\hline 8 & Garam alkaloida & + \\
\hline 9 & Antrasenoid & - \\
\hline 10 & Glikosida steroid & + \\
\hline 11 & Flavonoida & + \\
\hline 12 & Saponin & - \\
\hline
\end{tabular}

Tabel 2. Identifikasi senyawa kimia buah mbosi dengan GC-MS

\begin{tabular}{clcc}
\hline \hline No & \multicolumn{1}{c}{ Senyawa } & Total & $\%$ \\
\hline \hline 1. & Butyl cellosolve, 2-butoxy ethanol, ethylene glycol mono butyl ether & 70.51 & 11.1 \\
2. & Cinnamaldehyde & 2.22 & 0.35 \\
3. & Cinnamyl alcohol & 0.65 & 0.102 \\
4. & Diethylene glycol & 2.30 & 0.36 \\
5. & Erythritol & 53.71 & 8.48 \\
6. & Glycerol & 65.31 & 10.32 \\
7. & Hexadecanoic acid ethyl ester & 3.01 & 0.47 \\
8. & Hexadecanoic acid methyl ester & 2.11 & 0.33 \\
9. & Hexadecanoic acid palmitinic ester & 02.9 & 16.2 \\
10. & Linoleic acid & 11.79 & 1.86 \\
11. & Linolenic acid & 2.36 & 0.37 \\
12. & Oleic acid & 413.83 & 65.3 \\
13. & Ethyl oleat & 39.24 & 6.2 \\
14. & Methyl oleat & 29.58 & 4.67 \\
15. & Pseudocumene, trimethyl benzene & 0.51 & 0.08 \\
16. & Sec-butylamin & 1.08 & 0.17 \\
\hline \hline
\end{tabular}

Berdasarkan hasil identifikasi senyawa kimia pada buah mbosi maka terdapat kemungkinan adanya sifat antibakteri. Selain itu, hasil uji sitotoksik dengan Brine Shrimp 
Lethality Test (BSLT) menunjukkan bahwa LC $_{50}$ ekstrak alkohol buah mbosi adalah 347.95 ug (Chairul, 2003). Hal ini menunjukkan bahwa ekstrak alkohol buah mbosi mempunyai sifat toksisitas cukup baik sehingga kemungkinan juga dapat menghambat pertumbuhan bakteri. Uji antibakteri secara invitro dikatakan positif bila terbentuk daerah penghambatan pertumbuhan bakteri. Hasil uji antibakteri ekstrak methanol buah mbosi pada empat isolat bakteri Gram Negatif (Salmonella typhymurium, Salmonella typhii, Escherichia coli ATCC 25923, Pseudomonas sp.) ternyata tidak menunjukkan adanya penghambatan pertumbuhan, sedangkan pada bakteri Gram Positif (Staphylococcus aureus ATCC 25922, Bacilus subtilis, Staphylococcus epidermidis strain cowan ) penghambatan pertumbuhan hanya terdapat pada Staphylococcus aureus ATCC 25922 pada konsentrasi ekstrak 20\%. Senyawa yang kemungkinan dapat bersifat sebagai antibakteri adalah senyawa-senyawa aromatik diantaranya cinnamaldehyda, cinnamyl alkohol.

Tabel 3. Diameter daerah hambat (DDH) ekstrak metanol buah mbosi pada beberapa isolat bakteri

\begin{tabular}{lcc}
\hline \hline Isolat Bakteri & DDH pada konsentrasi ekstrak $(\mathrm{mm})$ \\
\hline S. typhimurium & $20 \%$ & $10 \%$ \\
S. typhii & - & - \\
E. coli ATCC 259 & - & - \\
Pseudomonas sp. & - & - \\
S. aureus ATCC 25922 & - & - \\
B. subtilis & 8 & - \\
S. epidermidis strain cowan & - & - \\
\hline \hline
\end{tabular}

Menurut Tang dan Eisenbrand (1992) cinnamaldehyde menunjukkan aktivitas bakterisidal terhadap beberapa spesies bakteri, selain itu cinnamaldehyde juga menunjukkan adanya sifat fungisidal, hipotermik dan antipiretik. Sedangkan cinnamyl alcohol merupakan alkohol aromatik yang kemungkinan juga bersifat sebagai antibakteri, dalam hal ini alkohol bersifat sebagai denaturan protein (Jawetz et al., 1996).

Tidak munculnya daerah penghambatan pertumbuhan pada isolat bakteri uji kemungkinan disebabkan senyawa kimia yang kemungkinan bersifat antibakteri (misal: flavonoida, cinnamaldehyde dan tanin) persentasenya sangat rendah sehingga belum mampu menghambat pertumbuhan bakteri pada konsentrasi ekstrak $10 \%$ dan $20 \%$. Selain itu kemungkinan adanya resistensi bakteri juga mengakibatkan tidak terbentuknya penghambatan pertumbuhan terhadap isolat bakteri yang diuji.

\section{Kesimpulan}

1. Senyawa kimia pada buah mbosi adalah lemak, asam lemak, sterol dan triterpenoida, tanin, gula pereduksi, garam alkaloida, glikosida steroid dan flavonoid.

2. Komponen kimia utama pada buah mbosi adalah asam lemak yaitu asam oleat $(65.3 \%)$.

3. Ekstrak metanol buah mbosi pada konsentrasi $20 \% \quad$ menghambat pertumbuhan S. aureus ATCC 25922.

\section{Daftar Pustaka}

Chairul. 2003. Pengujian nilai peroksida (POV) dan sitotoksik ekstrak etanol beberapa tumbuhan obat dari Taman Nasional Lore Lindu (Sulawesi Tengah). Laporan Teknik Puslit Biologi

Cuiley, J. 1984. Methodology for Analysis of Vegetables and Drugs. Faculty of Pharmacy. Bucharest, Rumania. 
Harborne, J.B. 1984. Phytochemical Methods. A Guide to Modern Techniques of Plant Analysis 2nd ed. Chapman and Hall, London.

Heyne, K. 1987. Tumbuhan Berguna Indonesia. Badan Penelitian dan Pengembangan Kehutanan. Departemen Kehutanan, Jakarta

Munson, J.W. Analisis Farmasi-Metode Modern. Penerjemah : Drs. Harjana, M.Sc, Airlangga Univ. Press. Surabaya.

Nugroho, B.W., Edrada, R.A., Gossiren, B., Wray, V., Witte, L. and Proksch, P. 1996. Insecticidal rocaglamide derivatives from Aglaia duppereana. Phytochemistry 44(8): 14551461.
Robinson, T. 1995. Kandungan Organik Tumbuhan Tinggi; terjemahan Kosasih Padmawinata. Penerbit ITB, Bandung.

Simmons, C.G. and Craver, J. 1980. Antibiotic sensitivity test using the disk method. Ustrlin Beureu Animal Health. Brisbane.

Tang, W. dan Eisenbrand, G. 1992. Chinese Drugs of Plant Origin. Chemistry, Pharmacology and Use in Traditional and Modern Medicine. Springer-Verlag. Berlin.

Tyler, V.E., Brady, L.R., Robbers, J.E. 1988. Pharmacognosy 9th ed. Lea and Febiger, Philadelphia 